\title{
Food resource utilization by juvenile Baltic cod Gadus morhua: a mechanism potentially influencing recruitment success at the demersal juvenile stage?
}

\author{
K. Hüssy ${ }^{1, *}$, M. A. St. John ${ }^{1}$, U. Böttcher ${ }^{2}$ \\ ${ }^{1}$ Danish Institute of Fisheries Research, Charlottenlund Castle, DK-2920 Charlottenlund, Denmark \\ ${ }^{2}$ Institut für Ostseefischerei Rostock, An der Jägerbäk 2, D-18069 Rostock, Germany
}

\begin{abstract}
Pelagic and demersal juvenile Baltic cod Gadus morhua L. were collected during surveys in the Bornholm Basin (Baltic Sea) in autumn 1994. Stomach contents were examined for prey composition in order to evaluate the potential importance of the pelagic and demersal habitats for recruitment success. Juvenile cod less than $40 \mathrm{~mm}$ fed exclusively on pelagic prey such as copepods and cladocerans. Between 40 and $50 \mathrm{~mm}$ the juveniles began to consume benthic prey such as mysids and amphipods; however, copepods were still the dominant food organisms. Between 50 and $70 \mathrm{~mm}$ the dominant prey items consumed were mysids and amphipods, with copepods comprising a minor component of the diet. Between 70 and $160 \mathrm{~mm}$ the juveniles' diet was composed exclusively of benthic prey with an increase in prey diversity. Mysids were slightly less important in the diet, while the abundance of polychaetes, decapods and fish increased with fish size. Amphipods remained almost constant in the diet of juveniles above $60 \mathrm{~mm}$ in length. These results indicate that a major change in food resource utilization started to occur at a fish length of $40 \mathrm{~mm}$, with the main change taking place at approximately $50 \mathrm{~mm}$, suggesting that juvenile Baltic cod make the transition to the benthic habitat at this length. This change in food preference is also reflected in the size of the prey items and the numbers of prey consumed. Pelagic juveniles consumed much smaller prey than their demersal conspecifics. Neither prey size nor prey numbers consumed by pelagic and small demersal juveniles from this study differed from prey reported to be taken by juvenile cod of corresponding size in the Atlantic and the North Sea. However, prey organisms consumed by demersal juvenile Baltic cod larger than $90 \mathrm{~mm}$ were much smaller, and prey numbers much higher, than those reported to be consumed by juveniles in other areas. The apparent overlap in food resource utilization among the different size groups of demersal juveniles observed in this study suggests that in years with low prey abundance, or high abundance of pelagic juveniles, strong intra-specific competition for food resources may affect the recruitment success of Baltic cod.
\end{abstract}

KEY WORDS: Pelagic and demersal juvenile cod · Food resource utilization $\cdot$ Settlement $\cdot$ Baltic Sea

\section{INTRODUCTION}

The recruitment of commercially important fish, such as cod, has long been of great interest to fisheries scientists as a precise knowledge of population size and recruitment is essential for optimal management of these fish stocks. Fluctuations in the year-class strength of fish stocks have traditionally been believed to be determined during the first year of life with variations in the survival of the larval stage believed to be

•E-mail: kh@dfu.min.dk the primary determinant of recruitment success (e.g. Hjort 1914, Cushing 1972, Lasker 1975, Bailey \& Houde 1989). Hypotheses developed were based on the timing of fish reproductive output and the peak plankton production and suggested that a mismatch in the timing of these events and the larval feeding environment could result in starvation of the first-feeding fish larvae. However, fisheries scientists have been largely unsuccessful in correlating larval abundance with recruitment success of e.g. Atlantic cod (Campana et al. 1989) and northern anchovy (Peterman et al. 1988). These observations suggest that recruitment of 
some fish stocks is not exclusively determined during the early larval stages. Despite this, fluctuations in year-class strength of fish stocks are still considered to be determined primarily by survival success during the first year of life and spawning stock biomass (e.g. Houde 1987, Bolz \& Lough 1988, Campana et al. 1989, Lough et al. 1989, Nordeide et al. 1994).

During the last decade researchers have examined processes occurring during the juvenile stages as possible agents determining the year-class strength. In particular density-dependent processes taking place during this period have been identified as critical (Cohen \& Grosslein 1982, Sissenwine 1984, Campana et al. 1989). Houde (1987) and Perry \& Neilson (1988) pointed out that mortality during the postlarval and juvenile stage of cod may be at least as critical as that occurring during the egg and larval life stages, and that changes in larval mortality, even though extensive, probably have a much smaller effect on recruitment than variations in juvenile mortality. The 2 primary agents of mortality are generally considered to be predation and adverse oceanographic conditions. The latter influence the distribution of fish eggs and larvae as well as the distribution and availability of their food items. However, the interaction between these 2 processes may play a critical role in determining recruitment success. Houde (1987) developed the 'stage duration' hypothesis, which suggests that the longer an individual spends in a certain life stage, the longer it will be exposed to stage-specific predation, thereby reducing its survival potential. The fastest growing individuals within a cohort will spend the shortest time in those vulnerable life stages and will therefore be exposed to predators for a shorter period of time than fishes with a slower growth rate. This hypothesis is supported by the observation that predation is generally size-dependent, with smaller cohorts facing the greatest risk of predation (McGurk 1986, Post \& Evans 1989a). However, recent studies by Litvak \& Leggett (1992) suggest that predators, when given a choice, select prey of a larger size when in the range of optimal prey size (Munk 1992). On the other hand, the faster an organism grows the more rapidly it escapes the optimal prey size window of potential predators hence reducing availability to size-specific predators (e.g. Parsons et al. 1983). Post \& Evans $(1989 \mathrm{~b})$ showed that the overwinter survival success of small juvenile yellow perch Perca flavescens is much lower than that of their larger conspecifics due to the larger individuals' better condition and presumably reduced predation rates. All these results suggest that the survival success of a juvenile fish increases with increasing growth rate and size at the onset of winter.

Tupper \& Boutilier (1995a, b) also suggest that high growth rates ensure better survival; however, accord- ing to these authors, this is not sufficient to ensure a higher survival success. They suggest that survival is also highly dependent on the complexity of the environment, with reefs and cobble providing optimal shelter in contrast to regions with sandy bottoms which offer little protection from predators. Hence, along with a high growth rate, the availability of appropriate shelter provided by a complex habitat also seems to be a crucial factor for the survival of juvenile cod. Tupper \& Boutilier $(1995 a, b)$ therefore suggest that the period of settlement and the following months is a critical period for juvenile cod due to the availability of appropriate habitat and predator avoidance.

As unfavourable growth conditions prolong stage duration, it is necessary to gain as much information as possible on the factors influencing the duration of a particular stage, growth rate variations being a prime factor. One process that can cause decreased growth, even when not leading to starvation, is suboptimal feeding. During the settling period juvenile cod face major changes in food type, size and availability, hence establishing this period as a potentially critical stage for the survival of juvenile cod. In order to predict the effect of the food resources available in any given location on the growth rate of juvenile cod, the feeding habits and food preferences of these fish have to be investigated thoroughly.

Research cruises performed in the Bornholm Basin (Baltic Sea) have identified the nearshore benthic habitat as a possible key environment utilized by the pelagic and demersal stages of 0 -group cod. In order to identify how these regions are utilized by settling stages and their potential influence on variations in the year-class strength of Baltic cod, the goal of the present research was to examine the food resources utilized by juvenile Baltic cod in these regions.

\section{MATERIALS AND METHODS}

Juvenile Baltic cod (0-group) were collected in the Bornholm Basin during 2 research cruises in the period between September 28 and November 4, 1994. A total of 641 juvenile cod in the size range 7 to $160 \mathrm{~mm}$ were caught using pelagic and demersal trawls. All trawls were towed at a speed of ca 3.5 knots for $30 \mathrm{~min}$. The stations and sample sizes are shown in Fig. 1.

After capture the fishes were immediately packed in plastic bags and stored in a $-20^{\circ} \mathrm{C}$ freezer. In the laboratory the samples were transferred to $a-70^{\circ} \mathrm{C}$ freezer to prevent further digestion. Upon thawing the standard length of each fish was measured.

The stomachs were removed and stored individually in a $4 \%$ solution of buffered formaldehyde. Inverted stomachs were discarded, leaving a total of 476 stom- 
achs for analysis. Individual stomachs were drained on filter paper for approximately 3 min and weighed. The contents were then removed and placed in a Petri dish with water; the stomach wall was washed, drained and weighed, whereafter the total stomach content was calculated. Empty stomachs were recorded separately.

Food items were identified to the lowest possible taxonomical level and assigned to habitat type (pelagic, intermediate and benthic) as described in Gosner (1971) and Mahon \& Neilson (1987). For each fish, total numbers of prey items and wet weights of the different taxonomical groups were recorded.

The lengths (total and thoracic) of all undigested food items were recorded together with their individual wet weights. The lengths of copepods and cladocerans were measured using a microscope, and their weights estimated using length/weight regressions described in Breteler et al. (1982) and Hernroth (1985).

In order to identify the length at which juvenile Baltic cod switch from pelagic habitat utilization to a demersal life, the prey items found in their stomachs were divided into 3 groups. These groups represent the prey item's habitat attachment, which was specified as pelagic, benthic or intermediate, according to Gosner (1971) and Mahon \& Neilson (1987). The last group label was assigned in those cases where the species were known not to be attached exclusively to one habitat, or to occur throughout the water column.

The relative abundance of the mysids, although they belong to an intermediate habitat type, was included in the relative abundance of truly benthic prey items. The mysid species consumed by the juveniles stay mainly near the bottom during the day and migrate up into the water column at night time (Rudstam et al. 1989, Hansson et al, 1990). The mysids found in the stomachs of fishes caught after dark were in an advanced state of digestion in comparison with those in the stomachs of fishes caught during the day, indicating that they had not been eaten recently.

In order to identify the length of settlement, the relative abundance, by both weight and numbers, of prey from pelagic and benthic habitats (see Table 1) was plotted against fish size. The threshold level of settling was defined by Bowman (1981) as the fish length (or age) at which more than $50 \%$ of the prey items consumed by number or weight are from a benthic source.

In order to examine the possible food range of juvenile cod, prey size was plotted against body size. As the prey items consumed vary greatly in their morphology, e.g. mysids, amphipods and molluscs, only their weight was considered. Some of the larger cod had consumed gobies in the trawl. These gobies were recovered totally undigested from the mouth and foregut of the fishes. The weights of these gobies were excluded.

\section{RESULTS}

\section{Size at settling}

The prey consumed by 0-group Baltic cod are listed in Table 1 for each size class individually. The species are listed in taxonomical order, together with the prey's habitat designation and the degree of dominance in the diet. These habitat designations mainly relate to the adults, even though many of the listed species have pelagic larvae. This circumstance was considered in cases where cod had consumed pelagic larvae of their prey.

According to Bowman's (1981) definition, the settling length of juvenile Baltic cod in October can be calculated as being approximately $50 \mathrm{~mm}$ as determined by both food item weight and numbers (see Fig. 2). A few individuals were observed to start feeding on benthic prey from a size of $42 \mathrm{~mm}$, while the largest fish 
observed feeding on pelagic prey was $73.5 \mathrm{~mm}$. The main settling took place in the size interval 45 to $53 \mathrm{~mm}$. Only 9 fish $(1.89 \%)$ consumed prey from pelagic and demersal origin concurrently.

\section{Food resource utilization before, during and after settling}

For each size class the food items were recorded separately as prey numbers and weight per fish. In Fig. 3 these data were combined into the following size classes: $5.0-49.5,50.0-89.5,90.0-119.5$ and 120.0-159.5 mm. Large prey items such as fish and large decapods tend to make up a larger proportion of the stomach contents when considered by weight rather than by numbers, while small prey items such as copepods make up a smaller proportion. A large part of the stomach contents by weight was observed to be completely digested material. The dominance by weight recorded here is an expression of the identifiable constituents.

Juvenile Baltic cod of standard length less than $50 \mathrm{~mm}$ preyed exclusively on pelagic food items such as copepods and cladocerans (see Fig. 3A). The most frequently consumed copepod species were Pseudocalanus minutus elongatus and Temora longicornis, while the species Acartia sp., Centropages hamatus and Oithona similis were consumed to a lesser extent. The most frequently consumed cladocerans were

Table 1. Prey composition of 0-group Baltic cod in taxonomical order together with their preferred habitat and their relative dominance by weight in the diet of the different size classes. Size classes are indicated as average standard fish length in mm of each size class $\pm 5 \mathrm{~mm}$. Index used for the dominance of the individual prey species: $1=$ dominant (more than $50 \%$ ), $2=$ intermediate

$(10-50 \%), 3=$ minor (less than $10 \%$ ). Habitat designations used are: $\mathrm{p}=$ pelagic, $\mathrm{i}=$ intermediate, $\mathrm{b}=$ benthic

\begin{tabular}{|c|c|c|c|c|c|c|c|c|c|c|c|c|c|c|c|c|c|}
\hline & \multirow[t]{2}{*}{ Prey species } & \multirow{2}{*}{$\begin{array}{l}\text { Habitat } \\
\text { type }\end{array}$} & \multicolumn{15}{|c|}{ Fish size (mm standard length) } \\
\hline & & & 15 & 25 & 35 & 45 & 55 & 65 & 75 & 85 & 95 & 105 & 115 & 125 & 135 & 145 & 155 \\
\hline \multicolumn{18}{|l|}{ Crustacea } \\
\hline \multirow[t]{4}{*}{ Cladocera } & $\begin{array}{l}\text { Bosmina longispina } \\
\text { maritima }\end{array}$ & $\mathrm{p}$ & 2 & 1 & 1 & 1 & 1 & & & & & & & & & & \\
\hline & Evadne nordmanni & $\mathrm{p}$ & 2 & 2 & 1 & 1 & 1 & & & & & & & & & & \\
\hline & Podon sp. & $\mathrm{p}$ & & 1 & & 1 & & & & & & & & & & & \\
\hline & Cladocera sp. & $\mathrm{p}$ & 2 & 1 & 1 & 1 & 1 & & & & & & & & & & \\
\hline \multirow[t]{6}{*}{ Copepoda } & Temora longicornis & $\mathrm{p}$ & & 1 & 2 & 1 & 1 & & 1 & & & & & & & & \\
\hline & $\begin{array}{l}\text { Pseudocalanus } \\
\quad \text { elongatus minutus }\end{array}$ & $\mathrm{p}$ & & 1 & 1 & 1 & 1 & 1 & 1 & & & & & & & & \\
\hline & Centropages hamatus & $\mathrm{p}$ & & 1 & 1 & 1 & & & & & & & & & & & \\
\hline & Acartia sp. & $\mathrm{p}$ & & 1 & & & & & & & & & & & & & \\
\hline & Oithona similis & $\mathrm{p}$ & & 1 & & & & & & & & & & & & & \\
\hline & Copepoda sp. & $\mathrm{p}$ & & 1 & 2 & 1 & 1 & & 1 & & & & & & & & . \\
\hline \multirow[t]{4}{*}{ Mysidacea } & Mysis mixta & $\mathrm{i}$ & & & & 1 & 1 & 1 & 2 & 2 & 1 & 1 & 1 & 1 & 1 & & 2 \\
\hline & Neomysis vulgaris & i & & & & 1 & 1 & 1 & 1 & 1 & 1 & 1 & 1 & 1 & 1 & & 1 \\
\hline & Mysis flexuosa & $\mathrm{i}$ & & & & & & & & & & & & 1 & & & \\
\hline & Mysidacea sp. & $\mathrm{i}$ & & & 1 & 3 & 4 & 3 & 2 & 1 & 1 & 1 & 2 & 1 & 1 & 1 & 1 \\
\hline \multirow[t]{3}{*}{ Amphipoda } & Gammarus locusta & b & & & & & & 1 & 1 & 1 & 1 & 1 & 2 & 1 & 1 & 2 & 2 \\
\hline & Gammarus sp. & $\mathrm{b}$ & & 1 & & 1 & & 1 & 1 & 1 & 1 & 2 & 1 & 1 & 1 & 2 & 1 \\
\hline & Hyperiidae sp. & $\mathrm{p}$ & & & & & & & 1 & & & & & & & & \\
\hline Decapoda & Crangon vulgaris & $\mathrm{b}$ & & & & & & & & 1 & 1 & 1 & 1 & 1 & 2 & 2 & 1 \\
\hline Cumacea & Diastylis rathkei & b & & & & 1 & & 1 & 1 & 1 & 1 & 1 & 1 & 1 & 1 & 1 & \\
\hline Isopoda & Mesidotea entomon & b & & & & & & & & & & & 1 & 1 & & 1 & \\
\hline \multicolumn{18}{|l|}{ Mollusca } \\
\hline \multirow[t]{2}{*}{ Bivalvia } & Mytilus edulis & b & & & & & & & 1 & 1 & 1 & 1 & 1 & 1 & 1 & 1 & 1 \\
\hline & Macoma sp. & b & & & & & & & & & & 1 & & & & & \\
\hline \multirow[t]{2}{*}{ Gastropoda } & Hydrobia ulvae & b & & & & & & & & 1 & & & 1 & & & & 1 \\
\hline & Mollusca sp. & $\mathrm{b}$ & & & & & & & 1 & & 1 & 1 & 1 & 1 & 1 & 1 & \\
\hline \multirow[t]{2}{*}{ Polychaeta } & Harmatoe sp. & $\mathrm{b}$ & & & & & 1 & & & 1 & 1 & & 1 & 1 & & & \\
\hline & Polychaeta sp. & $\mathrm{b}$ & & & & 1 & 1 & 1 & 1 & 1 & 1 & 1 & 1 & 1 & 1 & 1 & \\
\hline Pisces & $\begin{array}{l}\text { Pomatoschistus } \\
\text { minutus }\end{array}$ & $\mathrm{b}$ & & & & & & & 1 & 2 & 2 & 2 & 1 & 2 & 1 & 1 & 2 \\
\hline
\end{tabular}


Evadne nordmanni and Bosmina longispina maritima, with Podon sp. being less important as a food item. From a size of $40 \mathrm{~mm}$ onward a few juvenile cod began to prey on benthic organisms such as mysids and amphipods. The main species consumed were the mysids Mysis mixta, Neomysis vulgaris and the amphipod Gammarus locusta. Cumaceans (exclusively Diastylis rathkei) and Polychaeta were likewise preyed on to a minor extent. The copepods mentioned above were nevertheless still the most important food items in the diet of the juvenile cod, together with the somewhat larger, pelagic larvae of the above-mentioned mysids and amphipods.

In the size interval between 60 and $90 \mathrm{~mm}$ utilization of the copepods was low, while the importance of mysids and amphipods increased greatly, suggesting that the transition to the benthic habitat had been completed (see Fig. 3B). From a size of $80 \mathrm{~mm}$ onward juvenile Baltic cod fed exclusively on demersal food items, with a marked increase in the diversity of prey items consumed by this size group. The diet was expanded to include decapods, cumaceans, isopods, molluscs, polychaetes and fish (see Fig. 3C, D). Of the orders Decapoda, Cumacea and Isopoda only the species Crangon vulgaris, Diastylis rathkei and Mesidotea entomon were consumed. The molluscs utilized by the demersal stages were mainly Mytilus edulis, a few Hydrobia ulvae and Macoma sp. The only polychaete that could be identified with certainty was Harmatoesp. A possible reason for this is that these organisms easily break into fragments while being swallowed and are digested rapidly due to their soft body wall. In this study, juvenile Baltic cod from 80 to $160 \mathrm{~mm}$ length onward were observed to utilize only 1 fish species, this being Pomatoschistus minutus.

The importance of, in particular, polychaetes, cumaceans and fish in the diet of juvenile cod increased with increasing fish size. Decapods were likewise consumed only by larger fish, but were utilized by relatively few individuals. Molluscs were consumed to a minor extent by fish in all size classes above $60 \mathrm{~mm}$, comprising less than $5 \%$ of the total number of food animals per stomach and even less by weight (less than $0.5 \%$ ). The isopod Mesidotea entomon cannot be assumed to be a prey item of any importance to juvenile Baltic cod, as only a few fish had consumed a sin-
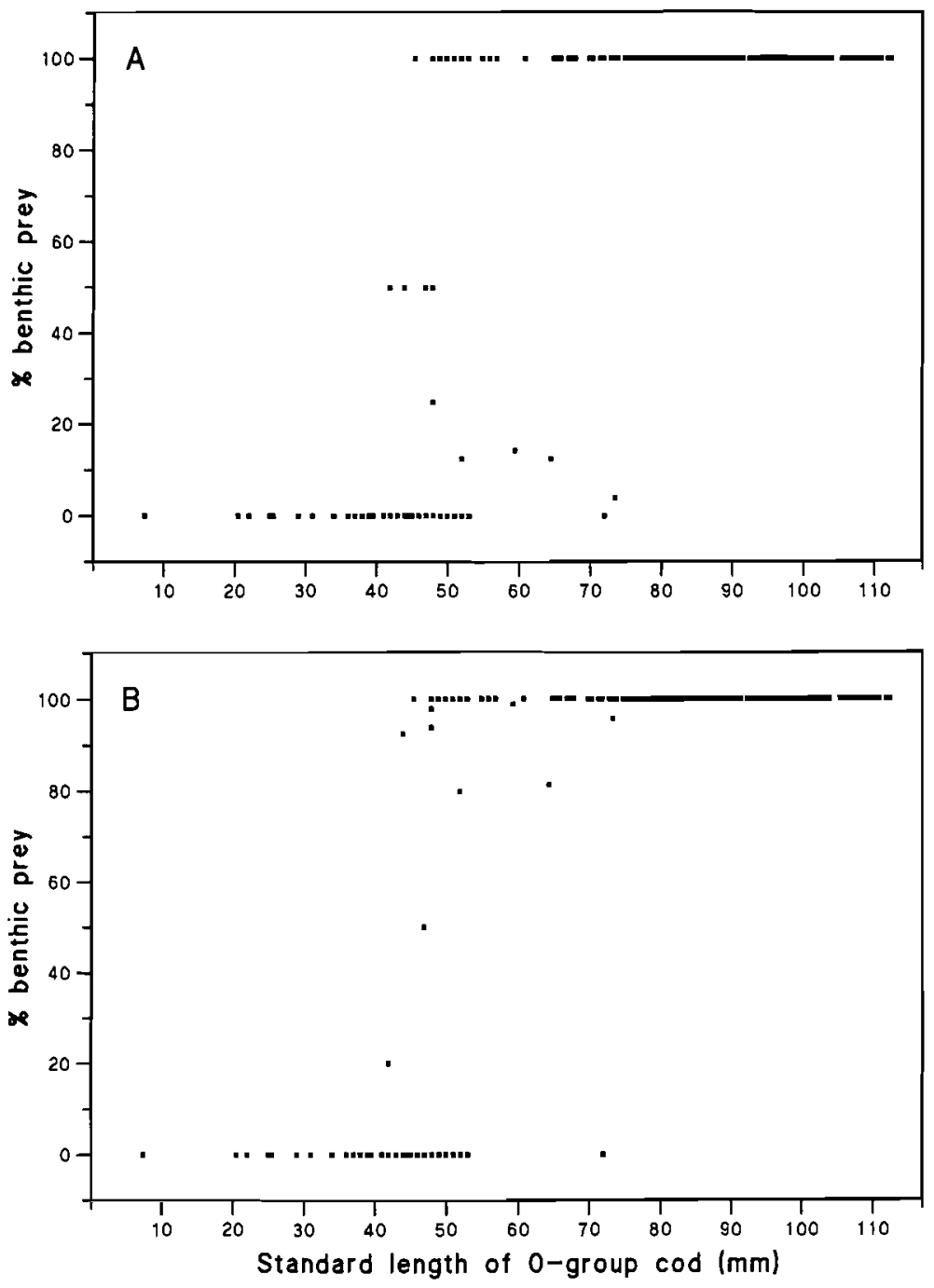

Fig. 2. Gadus morhua. Proportion of benthic prey items in the diet of 0 group Baltic cod by (A) prey abundance and (B) prey weight (formalin wet weight). Data points represent individual fish

gle individual of $M$. entomon. The importance of the mysids Mysis mixta and Neomysis vulgaris and the amphipod Gammarus locusta in the diet of juvenile cod larger than $60 \mathrm{~mm}$ decreased only gradually.

\section{Prey size and numbers}

The plot of prey weight against body size (Fig. 4) showed that juveniles with a body size smaller than $55 \mathrm{~mm}$ had been feeding on prey in the range $7 \times 10^{-6}$ to $3 \times 10^{-5} \mathrm{~g}$ whereas larger juveniles had been feeding on significantly larger prey in the range 0.005 to $0.15 \mathrm{~g}$ (ANOVA; $F_{(2,209)}=24.279, \mathrm{p}<0.001$ ). The size ranges of the prey items were 0.5 to $1 \mathrm{~mm}$ and 4 to $25 \mathrm{~mm}$ respectively. In order to compare the size of prey se- 

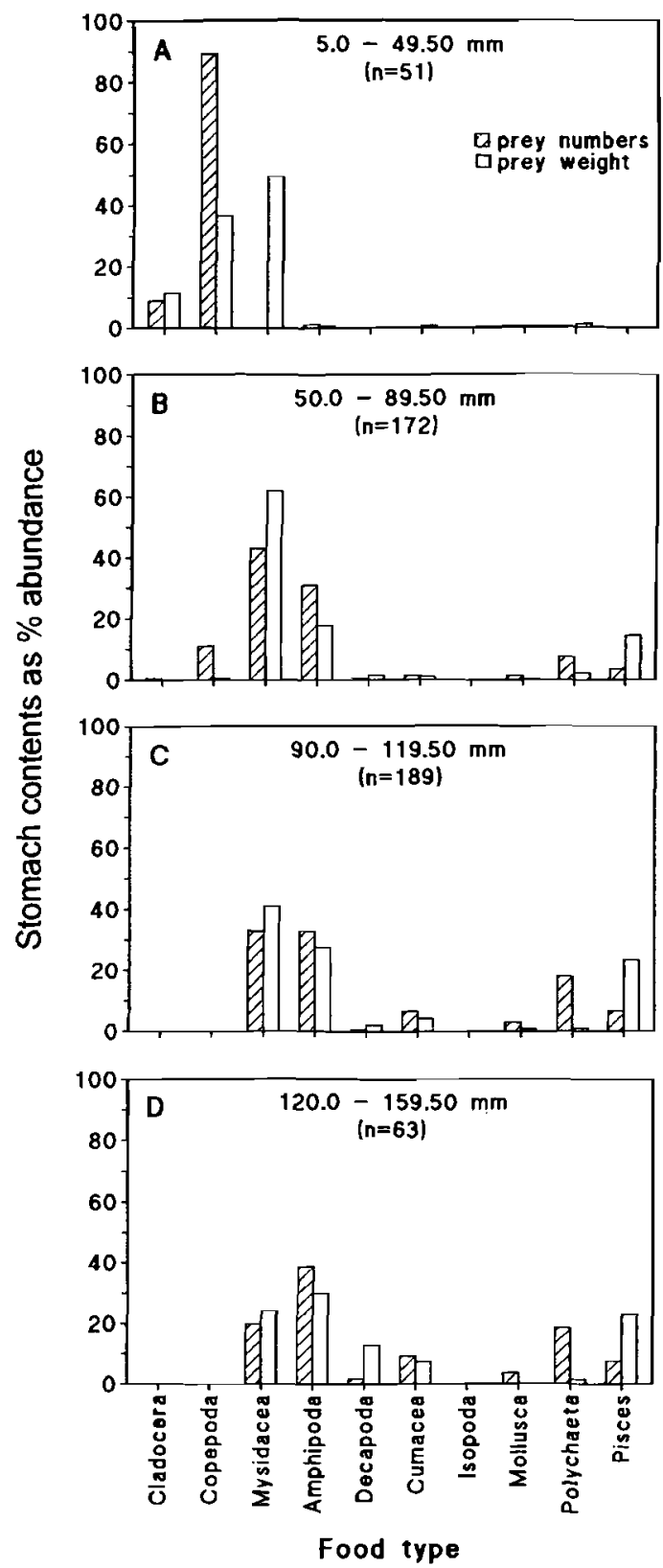

Fig. 3. Relative dominance of the individual taxonomical prey groups in the diet of 0 -group Baltic cod by prey abundance and prey weight in the size ranges (A) 5.0-49.5, (B) 50.0-89.5,

(C) $90.0-119.5$ and (D) $120.0-159.5 \mathrm{~mm}$

lected by juvenile Baltic cod with the prey size of juvenile cod from other areas an estimate of the individual size classes average prey size was obtained by combining data from Daan (1973), Robb \& Hislop (1980), Hawkins et al. (1985) and Fossum \& Ellertsen (1994). In the size range 5 to $50 \mathrm{~mm}$ there was no significant difference between the estimate of the average prey size and the prey size observed to be consumed by juvenile Baltic cod (ANOVA $\left.F_{(2,215)}=0.460, p=0.632\right)$, while a significant difference was observed in the size range 50 to $150 \mathrm{~mm}$ (ANOVA; $F_{\{2,191)}=19.653, \mathrm{p}<0.001$ ).

The plot of the number of food items in the stomach contents of the different size classes of juvenile cod is shown in Fig. 5. It shows that the fish consumed increasing amounts of food items from an average of 150 in the size range 20 to $30 \mathrm{~mm}$ up to $300-400$ at a size of $50 \mathrm{~mm}$. In the size range 50 to $60 \mathrm{~mm}$ the average amount of food items consumed dropped slightly to about 200 . The average numbers consumed fell to 5-6 food items in the diet of juveniles larger than $60 \mathrm{~mm}$ and slowly increased again from a size of 80 to $90 \mathrm{~mm}$.

Juvenile cod hence continue to feed on relatively small food items for a while after settling at a length of approximately $50 \mathrm{~mm}$ before switching to slightly larger prey. Pelagic fish in the size range from approximately 30 to $50 \mathrm{~mm}$ were feeding on prey smaller than the optimal size, as were demersal fish from a size of approximately $100 \mathrm{~mm}$.

\section{DISCUSSION}

The principal goals of this research were first to identify the food resources utilized by pelagic and demersal 0-group cod in the Baltic, and second, through the examination of their stomach contents, to estimate the size at which they switch to a demersal habitat utilization. In order to identify the size at settling it is necessary to assume that the food items found in the fish stomachs are indicative of the vertical distribution and the fish's utilization of this particular habitat type (Bowman 1981). Using these assumptions, the size at which juvenile Baltic cod switch to the demersal habitat was determined to range between 42 and 73 $\mathrm{mm}$ standard length, with the majority settling at a length between 45 and $53 \mathrm{~mm}$. Baltic cod have a very prolonged spawning season, from March through to September/October, with peak spawning occurring in May/June (Bagge \& Thurow 1993). Hence, due to the timing of the surveys performed, the settling length observed in this study may not be applicable to all cohorts. Eggs and larvae from spawning occurring at times of the season other than those investigated in this study will encounter different hydrographic regimes and feeding conditions, potentially leading to different growth rates and settling sizes. However, the results from this study are in agreement with the results from other studies. The settling length of Atlantic cod was reported to range between 60 and $80 \mathrm{~mm}$ (Bolz \& Lough 1988) and between 30 and $60 \mathrm{~mm}$ (Tupper \& Boutilier 1995a), with North Sea cod reported to settle at a length of between 50 and $60 \mathrm{~mm}$ (Robb \& Hislop 1980). 
Fig. 4. Average weight of prey items consumed by 0 -group Baltic cod. Data points ( $\bullet$ ) represent average weight of prey consumed by individual fish examined in this study. An estimate of juvenile cod's average prey weight was obtained by combining data from Daan (1973) (•), Robb \& Hislop (1980) ( $\star$ ), Hawkins et al. (1985) (4), and Fossum \& Ellertsen (1994) («). The data points shown represent average prey weights per fish size of cod from different areas in the North

Sea and the Atlantic Ocean

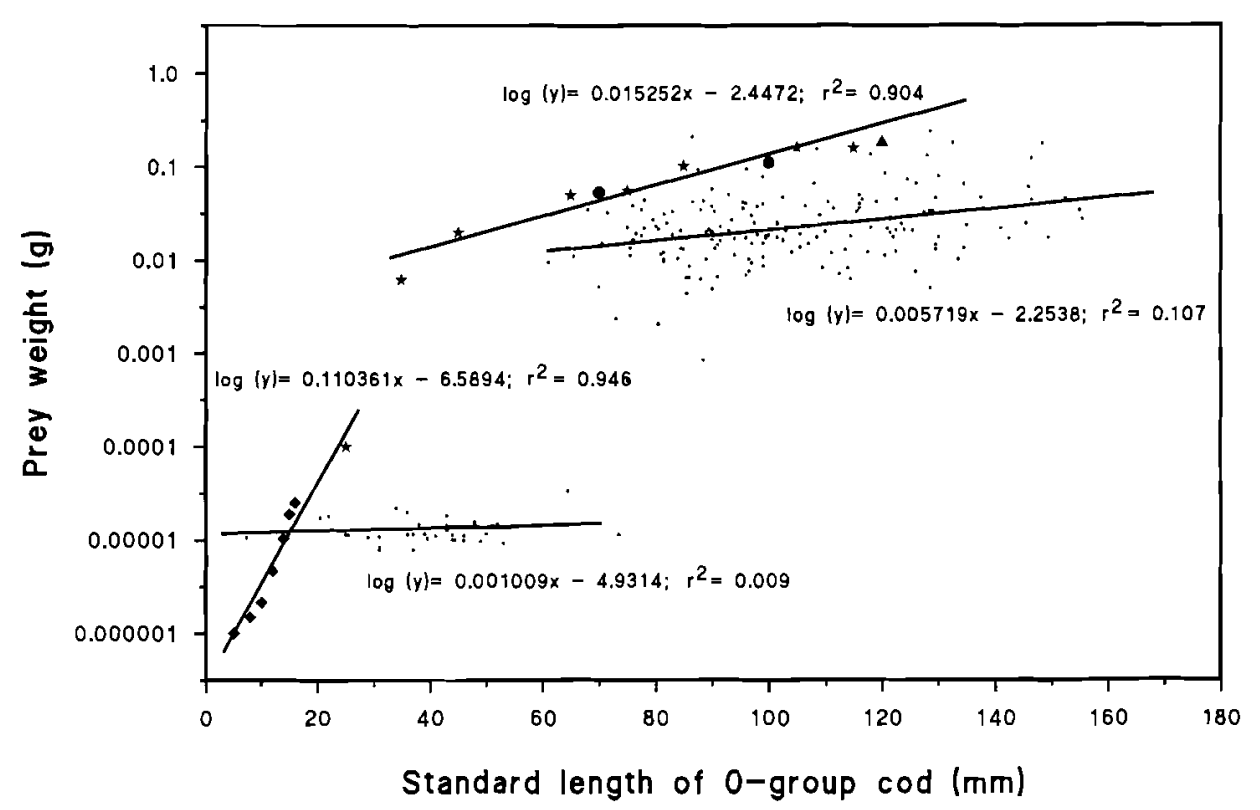

Several studies have addressed the abruptness with which the transition from an exclusively pelagic to a demersal habitat utilization occurs, with different results. Bowman (1981) reported that the size at which $50 \%$ of Atlantic cod had settled was approximately $80 \mathrm{~mm}$. However, fish as small as $30 \mathrm{~mm}$ were observed to consume small amounts of benthic prey. Hence, on the basis of these observations he concluded that the transition to demersal habitat utilization is a gradual process. Similar results have been obtained for Icelandic cod (Pálsson 1980). Bolz \& Lough (1988) investigated growth and settlement of 0 -group Atlantic cod through examination of otolith microstructure. They suggested that a change in metabolism occurring during settling would be visible in the otolith microstructure as is the case for observed structural changes occurring during other stressful periods (i.e. hatching and yolk-sac absorption). These authors observed no changes in the otolith structure during the expected transition period (60 to $80 \mathrm{~mm}$ length), leading to the conclusion that the transition to the demersal stage was not stressful and must therefore be a gradual process.

The observation that only very few fish investigated in the present study had consumed prey from both
Fig. 5. Prey numbers in the stomach contents of different size classes of 0 -group Baltic cod $( \pm 95 \%$ confidence limits $)$

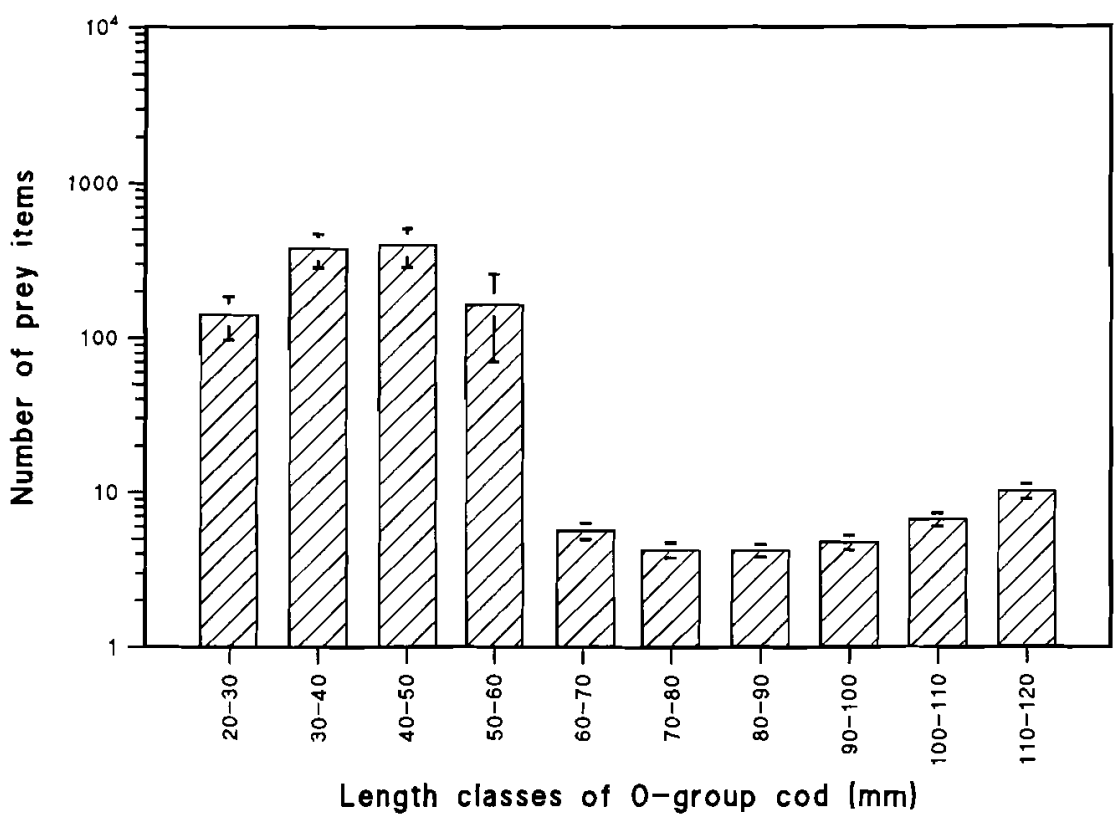


pelagic and demersal origin seems to indicate that the transition from one habitat to the other is an abrupt process for Baltic cod. Abrupt transition to the demersal habitat has previously been observed for gadoids by Koeller et al. (1986) and Mahon \& Neilson (1987). Through the utilization of stomach content analysis, these authors concluded that the transition period for juvenile Scotian Shelf haddock is of short duration.

Surprisingly, there is little variation in the reported transition times for a whole cohort. Koeller et al. (1986) found that the transition to the demersal life for a whole cohort took 27 d. Mahon \& Neilson (1987) estimated this period to be of approximately 4 wk duration. Juvenile cod in the present study were observed to settle in a $30 \mathrm{~mm}$ size interval, with most of the settlement taking place within a $10 \mathrm{~mm}$ size interval. Juvenile Baltic cod have a growth rate of approximately $0.73 \mathrm{~mm} \mathrm{~d}^{-1}$ according to Linkowski \& Kowalewska-Pahlke (1993), similar to growth rates of $0.71 \mathrm{~mm} \mathrm{~d}^{-1}$ observed in other stocks (e.g. Bolz \& Lough 1988, Tupper \& Boutilier 1995a). Using these growth rates, the transition period for a whole cohort of juvenile Baltic cod can be estimated to be of approximately $40 \mathrm{~d}$ duration, with the majority of the juveniles settling within $14 \mathrm{~d}$, an estimate similar to that of Tupper \& Boutilier (1995b).

The dominance of crustaceans in the food of juvenile cod observed in this study is in agreement with other studies on the food resource utilization of juvenile cod in the Atlantic (Bowman 1981), in the North Sea (Daan 1973, Robb \& Hislop 1980), in the Western Baltic Sea (Arntz 1974) and in Icelandic waters (Pálsson 1973, 1980). These authors reported the diet of pelagic juvenile cod to consist of copepods, with a preference for the larger species. The species composition of the demersal juveniles diet, however, differed between the areas investigated, depending on the food items available. The diet of the juvenile cod from the previously mentioned areas changed gradually towards increasing diversity with increasing fish size. These authors reported that newly settled juveniles preferentially consumed euphausiids, amphipods, cumaceans and mysids, with a transition to decapods (mainly Crangonidae and Pandalidae) with increasing fish size. If large decapods were not available, small fish were consumed (Daan 1973, Arntz 1974, Pálsson 1980, Bowman 1981). The proportion of polychaetes in the diet of juvenile demersal cod was reported to be relatively constant and of minor importance (approximately $10 \%$ by weight), while the share of molluscs never exceeded $1 \%$. However, it is very likely that the occurrence of polychaetes in the stomach contents was underestimated, as they are more rapidly digested than crustaceans due to their soft body wall (Mattson
1990). In all of these systems a change towards greater diversity in the food spectrum took place after the fishes had settled to the bottom, concurrent with a change in feeding behaviour.

The diversity of food consumed by cod has been reported to be one of the highest among fish species investigated in the northeastern Atlantic (Mattson 1990); however, the proportion of the entire prey range which is normally utilized has been reported to be one of the lowest due to selection for the most abundant prey. In the Baltic Sea, the diversity of food available to cod is much lower due to the lower diversity of the habitat (S. Mattson pers. comm.), hence leading to a lower diversity of food consumed.

Both prey size and prey numbers consumed by the different size classes in this study reflected the transition from pelagic to demersal habitat utilization and the low diversity of the Baltic habitat (with respect to potential prey organisms). Examination of the size of the average prey item consumed shows that pelagic and demersal juveniles consume prey from a relatively restricted size range during these stages. In both groups ( 5 to 50 and 50 to $150 \mathrm{~mm}$ ) cod fed initially on prey of presumably optimal size, but the size of the prey consumed did not increase with increasing fish size. Pelagic juveniles are known to continue feeding on small prey items such as copepods to the size of settlement unless larger prey items are available (Pálsson 1973, 1980, Robb \& Hislop 1980, Bowman 1981, Robb 1981, Mahon \& Neilson 1987). However, in no other region was the size of food items of demersal juveniles reported to be as small as those from this study. Daan (1973), Robb \& Hislop (1980), Robb (1981) and Hawkins et al. (1985) reported that as juvenile cod increase in size they reduce the numbers of prey items consumed, selecting lower numbers of prey of larger size. They stated that this would tend to decrease intraspecific competition for food between early-spawned and late-spawned individuals of a year class. Juvenile Baltic cod in this study consumed comparatively high numbers of small prey, suggesting that optimal sized prey items were unavailable thus forcing them to utilize prey items of less than optimal size.

Mattson (1990) found that juvenile cod generally selected prey items which were most abundant in the environment. This result is supported by Keats \& Steele (1992) in an investigation on juvenile cod off the coast of Newfoundland, and by Daan (1973), who attributed the differences in prey items utilized by juvenile North Sea cod to different prey availabilities and to utilization of the most abundant prey.

In the present study, juvenile cod were observed to utilize an increasing spectrum of prey with increasing fish size. However, the main component of the demersal juvenile diet was primarily mysids and to a lesser 
degree amphipods (see Fig. 3C, D), prey of suboptimal size for juvenile cod of this size.

Obviously, demersal juveniles over the whole size range considered here had to a certain extent utilized similar food resources. Selection for the most abundant prey item, which Mattson (1990) found to occur in juvenile Atlantic cod, is a reasonable explanation for this phenomenon. As the larger individuals have a greater growth rate (Tupper \& Boutilier 1995a) and consume larger amounts of food (Daan 1973, Arntz 1974, Hawkins et al. 1985 and this study), it seems possible that intra-specific competition for food between smaller (late-spawned) and larger (early-spawned) juveniles could be taking place.

In this study we have demonstrated that juvenile Baltic cod from the time of settlement depend heavily on small crustaceans such as mysids and amphipods, organisms which occur most frequently in the nearshore habitats down to a depth of $40 \mathrm{~m}$ (Persson 1982, Aschan 1988). This identifies the shallow, nearshore areas of the Baltic Sea as being nursery areas for the newly settled juveniles and being potentially important to the recruitment success of Baltic cod. As high growth rates are assumed to be essential for the survival of the juveniles by reducing exposure to sizespecific predators and overwinter mortality, fluctuations in the population size of the preferred prey organisms may affect the growth and survival of the juvenile cod and thereby the recruitment success of Baltic cod.

The present results suggest that the juvenile demersal stage may very well be a key period in the life history of Baltic cod, a period in which year-class strength can be influenced by intra-specific competition for limited food resources. Hence, in years with suitable conditions for survival of eggs and larvae of Baltic cod, due to inflow of oxygen rich salt water from the North Sea (e.g. MacKenzie et al. 1996), density-dependent processes acting on the demersal juvenile stage may reduce recruitment success due to limited food availability.

Acknowledgements. We thank the crew of the Danish research vessel 'Dana' for logistical assistance during the cruise programs as well as collaborators in the Baltic CORE program for scientific discussions; in particular we thank Drs J. Tomkiewicz and $\mathrm{H}$. Mosegaard. This research was in part funded by a grant from the European Union (AIR2-94-1226) and the Danish Institute for Fisheries Research.

\section{LITERATURE CITED}

Arntz WE (1974) Periodicity of diel food intake of cod Gadus morhua in the Kiel Bay. Oikos 15:138-145

Aschan M (1988) Soft bottom macrobenthos in a Baltic archipelago: spatial variation and optimal sampling strategy. Ann Zool Fenn 25:153-164
Bagge O, Thurow F (1994) The Baltic cod stock: fluctuations and possible causes. ICES Mar Sci Symp 198:254-268

Bailey KM, Houde ED (1989) Predation on eggs and larvae of marine fishes and the recruitment problem. Adv Mar Biol $25: 1-83$

Bolz GR, Lough RG (1988) Growth through the first six months of Atlantic cod, Gadus morhua, and haddock, Melanogrammus aeglefinus, based on daily otolith increments. Fish Bull US 86:223-235

Bowman RE (1981) Food of 10 species of Northwest Atlantic juvenile groundfish. Fish Bull US 79:200-206

Breteler WCMK, Fransz HG, Gonzales SR (1982) Growth and development of four calanoid copepod species under experimental and natural conditions. Neth J Sea Res 16: $195-207$

Campana SE, Frank KT, Hurley PCF, Koeller PA, Page FH, Smith PC (1989) Survival and abundance of young Atlantic cod (Gadus morhua) and haddock (Melanogrammus aeglefinus) as indicators of year-class strength. Can J Fish Aquat Sci 46:171-182

Cohen EB, Grosslein MD (1982) Food consumption by silver hake (Merluccius bilinearis) on Georges Bank with implications for recruitment. In: Calliet GM, Simenstadt CA (eds) Gutshop '81, fish food habits studies. Proc 3rd Pacific Workshop, Washington Sea Grants, Univ Washington Press, Seattle, p 286-294

Cushing $\mathrm{DH}$ (1972) The production cycle and the numbers of marine fish. Symp Zool Soc Lond 29:213-232

Daan N (1973) A quantitative analysis of the food intake of North Sea cod, Gadus morhua. Neth J Sea Res 6(4): 479-517

Fossum $P$, Ellertsen B (1994) Gut content analysis of first feeding cod larvae (Gadus morhua) sampled at Lofoten, Norway, 1979-1986. ICES Mar Sci Symp 198:432-437

Gosner KL (1971) Guide to identification of marine and estuarine invertebrates, Cape Hatteras to the Bay of Fundy. Wiley Interscience, New York

Hansson S, Larsson U, Johansson S (1990) Selective predation by herring and mysids, and zooplankton community structure in a Baltic Sea coastal area. J Plankton Res 12(5): 1099-1116

Hawkins AD, Soofiani NM, Smith GW (1985) Growth and feeding of juvenile cod (Gadus morhua L.). J Cons Int Explor Mer 42:11-32

Hernroth L (1985) Recommendations on methods for marine biological studies in the Baltic Sea. Baltic Mar Biol 10:1-32

Hjort J (1914) Fluctuations in the great fisheries of Northern Europe viewed in the light of biological research. Rapp PV Réun Cons Int Explor Mer 20:1-228

Houde ED (1987) Fish early life dynamics and recruitment variability. Am Fish Soc Symp 2:17-29

Keats DW, Steele DH (1992) Diurnal feeding of juvenile cod (Gadus morhua) which migrate into shallow water at night in eastern Newfoundland. J Northwest Atl Fish 13:7-14

Koeller PA, Hurley PCF, Perley P, Neilson JD (1986) Juvenile fish surveys on the Scotian Shelf: implications for yearclass size assessments. J Cons Int Explor Mer 43:59-76

Lasker R (1975) Field criteria for survival of anchovy larvae: the relation between inshore chlorophyll maximum and successful first feeding. Fish Bull US 73:453-462

Linkowski TB, Kowalewska-Pahlke M (1993) Growth of juvenile Baltic cod estimated from daily growth increments in otoliths. ICES (Int Counc Explor Sea) CM 1993/J:19

Litvak MK, Leggett WC (1992) Age and size-selective predation on larval fishes: the bigger-is-better hypothesis revisited. Mar Ecol Prog Ser 81:13-24

Lough RG, Valentine PC, Potter DC, Auditore PJ, Bolz GR, 
Neilson JD, Perry RI (1989) Ecology and distribution of juvenile cod and haddock in relation to sediment type and bottom currents on eastern Georges Bank. Mar Ecol Prog Ser 56:1-12

MacKenzie B, St. John M, Wieland K (1996) Eastern Baltic cod: perspectives from existing data on processes affecting growth and survival of eggs and larvae. Mar Ecol Prog Ser 134:265-281

Mahon R, Neilson JD (1987) Diet changes in Scotian Shelf haddock during the pelagic and demersal phases of the first year of life. Mar Ecol Prog Ser 37:123-130

Mattson S (1990) Food and feeding habits of fish species over a soft sublittoral bottom in the northeast Atlantic. Sarsia 75:247-260

McGurk MD (1986) Natural mortality of marine pelagic fish eggs and larvae: role of spatial patchiness. Mar Ecol Prog Ser 31:227-242

Munk P (1992) Foraging behaviour and prey size spectra of larval herring Clupea harengus. Mar Ecol Prog Ser 80: $149-158$

Nordeide JT, Fosså JH, Smedstad OM (1994) Testing if yearclass strength of coastal cod, Gadus morhua L., can be determined at the juvenile stage. Aquacult Fish Manage 25(1):101-116

Pálsson OK (1973) Nahrungsuntersuchungen and den Jugendstadien (0-Gruppen) einiger Fischarten in isländischen Gewässern. Ber Dtsch Wiss Komm Meeresforsch 23:1-32

Pálsson OK (1980) Über die Biologie junger Gadiden der Altersgruppen 0, I und II in isländischen Gewässern. Meeresforschung 28:101-145

Parsons TR, Takahashi M, Hargrave B (1983) Biological oceanographic processes, 3rd edn. Pergamon Press, Oxford

Perry Rl, Neilson JD (1988) Vertical distributions and trophic interactions of age-0 Atlantic cod and haddock in mixed

This article was submitted to the editor and stratified waters of Georges Bank. Mar Ecol Prog Ser 49:199-214

Persson LE (1982) Macrozoobenthic associations of the Hanø Bight, southern Baltic. Sarsia 67:93-106

Peterman RM, Bradford MJ, Lo NCH, Method RD (1988) Contribution of early life stages to interannual variability in recruitment of northern anchovy (Engraulis mordax). Can J Fish Aquat Sci 45:8-16

Post JR, Evans DO (1989a) Experimental evidence of sizedependent predation mortality in juvenile yellow perch. Can J Zool 67:521-523

Post JR, Evans DO (1989b) Size-dependent overwinter mortality of young-of-the-year yellow perch (Perca flavescens): laboratory, in situ enclosure, and field experiments. Can J Fish Aquat Sci 46:1958-1968

Robb AP (1981) Observations on the food and diel feeding behaviour of pelagic 0 -group gadoids in the northern North Sea. J Fish Biol 18:183-194

Robb AP, Hislop JRG (1980) The food of five gadoid species during the pelagic 0-group phase in the northern North Sea. J Fish Biol 16:199-217

Rudstam LG, Danielsson K, Hansson S, Johansson S (1989) Diel vertical migration and feeding patterns of Mysis mixta (Crustacea, Mysidacea) in the Baltic Sea. Mar Biol $101: 43-52$

Sissenwine MP (1984) Why do fish populations vary? In: May RM (ed) Exploitation of marine communities. SpringerVerlag, New York, p 59-94

Tupper M, Boutilier RG (1995a) Size and priority at settlement determine growth and competitive success of newly settled Atlantic cod. Mar Ecol Prog Ser 118:295-300

Tupper M, Boutilier RG (1995b) Effects of habitat on settlement, growth, and postsettlement survival of Atlantic cod (Gadus morhua). Can J Fish Aquat Sci 52:1834-1841

Manuscript received: December 2, 1996

Revised version accepted: May 30, 1997 